\title{
Feeding lactating dairy cattle long hay separate from the total mixed ration can maintain dry matter intake during incidents of low rumen $\mathrm{pH}^{1}$
}

\author{
A. D. Kmicikewycz and A. J. Heinrichs ${ }^{2}$ \\ Department of Animal Science, The Pennsylvania State University, University Park 16802
}

\begin{abstract}
The objective of this study was to investigate effects of offering dry hay of different quality and length on rumen $\mathrm{pH}$ and feed preference in lactating dairy cows. Eight rumen-cannulated Holstein cows $(104 \pm 34 \mathrm{~d}$ in milk, body weight of $601 \pm 116 \mathrm{~kg}$, and parity of $2.38 \pm 1.69$; mean \pm standard deviation) were used in a replicated $4 \times 4$ Latin square design. Each period encompassed $21 \mathrm{~d}$ divided into 5 phases: adaptation (d 1 to 14 ), with ad libitum total mixed ration (TMR); baseline (d 15 to 17), with ad libitum TMR; restricted feeding (d 18), with cows fed for $75 \%$ of baseline dry matter intake; challenge (d 19), with $4 \mathrm{~kg}$ (as-fed) of finely ground wheat mixed into the digesta of each cow via rumen cannula before feeding; and recovery (d 20 to 21), with ad libitum TMR. Cows were assigned to squares by parity and randomly assigned to treatments. Treatments were $5.2 \%$ low-quality hay TMR (CL), $5.2 \%$ high-quality hay TMR $(\mathrm{CH}$; both hays were chopped and included in TMR), TMR with $5.2 \%$ supplemental long low-quality hay (TMR+L), and TMR with $5.2 \%$ supplemental long high-quality hay $(\mathrm{TMR}+\mathrm{H}$; both hays were unprocessed and fed separate from TMR). Low-quality hay contained $8.6 \%$ crude protein and $67.1 \%$ neutral detergent fiber, whereas high-quality hay contained $14.4 \%$ crude protein and $56.2 \%$ neutral detergent fiber. Animals were housed individually, milked twice per day, and fed once per day for 10\% refusal rate. Data were analyzed using PROC MIXED of SAS (SAS Institute Inc., Cary, NC). Subacute ruminal acidosis challenge decreased weighted average rumen $\mathrm{pH}$ from 5.72 to 5.51. Cows fed TMR+L had higher rumen $\mathrm{pH}$ compared with CL and TMR $+\mathrm{H}$ on d 19. During d 20, cows fed chopped hay had higher rumen $\mathrm{pH}$ than cows fed supplemental long hay. Cows fed supplemental long hay had greater dry matter intake during baseline and challenge days compared with when hay was chopped
\end{abstract}

\footnotetext{
Received May 27, 2014.

Accepted August 11, 2014.

${ }^{1}$ This research is a component of NC-2042; Management Systems to Improve the Economic and Environmental Sustainability of Dairy Enterprises.

${ }^{2}$ Corresponding author: ajh@psu.edu
}

and included in the TMR. Minimal differences among diets were found for TMR particle size selection during the challenge day; however, cows had a greater preference for high-quality long hay during recovery days. Milk production averaged $38.3 \mathrm{~kg} / \mathrm{d}$ and did not differ among treatments. Fat, protein, and lactose yields were also not different among treatments. Milk fatty acid profile was altered by treatment. The TMR $+\mathrm{L}$ and $\mathrm{CH}$ treatments increased production of cis-9,trans-11 conjugated linoleic acid. Results of this study indicate that feeding TMR plus supplemental long hay can maintain dry matter intake during incidents of and recovery from periods of low ruminal $\mathrm{pH}$.

Key words: subacute ruminal acidosis, ruminal $\mathrm{pH}$, dry matter intake

\section{INTRODUCTION}

Subacute ruminal acidosis is an important nutritionally linked digestive disorder affecting high-producing dairy cattle, and despite best management practices, SARA can be found in well-managed, high-producing herds (Nocek, 1997). High-producing dairy cattle require large amounts of dietary energy to meet the demands of milk production. Accommodating this energy requirement necessitates feeding large amounts of concentrate and by-product feeds. Concentrate and by-product feeds, however, contain large quantities of highly fermentable carbohydrates that can result in a buildup of organic acids (VFA) in the rumen and reduce rumen buffering capacity (Kleen et al., 2003; Krause and Oetzel, 2006). Accumulation of excessive VFA in the rumen can depress $\mathrm{pH}$ for prolonged periods each day $(<5.5$ for $>3$ h/d; Kleen et al., 2003; Gozho et al., 2005), initiating SARA.

Forages in general, and long forage in particular, promote chewing and saliva secretion, which buffers VFA production from feed digestion and can have a significant effect on rumen pH (Mertens, 1997). Cows consuming longer forage particles and diets high in physically effective fiber (peNDF) spend more time eating (per unit of DM) and ruminating, which increases the flow of saliva and its associated buffers into the rumen. Diet fiber content is a primary factor affecting chewing 
activity and is believed to be an indicator of the diet's effect on rumen health and function (Yang et al., 2001).

Several studies have provided evidence that dairy cows will select feeds with high ruminal buffering capacity in an attempt to attenuate effects of low ruminal $\mathrm{pH}$ to improve rumen health and DMI. Keunen et al. (2002) demonstrated that lactating dairy cows induced with SARA increased their preference for long alfalfa hay over pelleted alfalfa. Feeding a higher proportion of forage to increase dietary NDF content can lower the starch concentration of the diet and decrease the rate of fermentation of the diet. When challenged with a highstarch diet, cows sorted for longer particles in a TMR (Beauchemin and Yang, 2005; Yang and Beauchemin, 2006). DeVries et al. (2008) also used a rumen challenge model to induce SARA in early and mid-lactation Holstein cows. Changes in eating behavior were measured by determining the particle size distribution of offered and refused feeds. After the rumen challenge, lactation cows generally increased their sorting for medium particles and against short and fine particles when challenged. In addition, Maulfair et al. (2013) showed that during a bout of SARA, cows were able to alter their diet preference for higher peNDF and slower starch fermentability.

As milk production capacity of dairy cows continues to increase, the potential health risks and production losses associated with consuming high-energy diets need to be addressed. Further, despite evidence of the ability of dairy cattle to alter eating behavior or diet choice based on their rumen environment, no research has been published observing the influence of SARA on the diet preference and DMI of lactating dairy cows fed diets differing in hay quality (low vs. high) and length (chopped in the TMR or long and separate from the TMR). Therefore, the objectives of this experiment were to induce a bout of SARA in lactating dairy cows that had ad libitum access to 4 distinct diets varying in hay quality and length and to determine how SARA affected TMR feed preference and DMI in lactating dairy cows in this situation.

\section{MATERIALS AND METHODS}

\section{Cows, Experimental Design, and Diets}

All experimental procedures were approved by The Pennsylvania State University Institutional Animal Care and Use Committee (University Park; PSU IACUC \#40945). Eight ruminally cannulated Holstein cows, averaging $104 \pm 34$ DIM, weighing $601 \pm 116 \mathrm{~kg}$, and with a parity of $2.38 \pm 1.69$ (mean $\pm \mathrm{SD}$ ), were used in this study. The experimental design consisted of 2 replicated $4 \times 4$ Latin squares with a $2 \times 2$ facto- rial arrangement of treatments. Cows were assigned to squares by parity and DIM and randomly assigned to 1 of 4 treatments.

Treatments were designed to study the effects of 2 lengths and 2 qualities of orchardgrass hay (Dactylis glomerata L.): $5.2 \%$ chopped low-quality hay TMR (CL), $5.2 \%$ chopped high-quality hay TMR ( CH), TMR with $5.2 \%$ supplemental long low-quality hay $(\mathbf{T M R}+\mathbf{L})$, and TMR with $5.2 \%$ supplemental long high-quality hay $(\mathbf{T M R}+\mathbf{H})$. For treatments TMR $+\mathrm{L}$ and TMR $+\mathrm{H}$, hay was not processed and was fed as a supplement separate from the TMR. The first cut of low-quality hay contained $8.6 \% \mathrm{CP}$ and $67.1 \% \mathrm{NDF}$, and the second cut of high-quality hay contained $14.4 \%$ $\mathrm{CP}$ and $56.2 \%$ NDF (Table 1). Low- and high-quality hay were chopped using a Roto Grind bedding chopper (Burrows Enterprises LLC, Greeley, CO). Mean particle size for chopped low- and high-quality hay was 9.4 and $9.6 \mathrm{~mm}$, respectively. Diets were offered to cows in tie-stalls, with feed mangers divided into halves via a plywood panel that eliminated cross-contamination of TMR and supplemental unprocessed hay. Except for altering hay quality and length and providing hay in the TMR or separate from the TMR, the 4 treatment diets contained identical ingredients and proportions. Diet ingredients (\% of ration DM) were corn silage (43.3), alfalfa haylage (14.4), orchardgrass hay (5.2), cottonseed hulls (3.6), dry ground corn (18.1), canola meal (3.6), roasted split soybeans (9.0), mineral and vitamin mix (2.5), and Optigen (Alltech Inc., Nicholasville, $\mathrm{KY} ; 0.3$ ). The mineral and vitamin mix contained $45.8 \%$ dried corn distillers grains with solubles, $35.8 \%$ limestone $(38 \% \mathrm{Ca}), 8.3 \%$ magnesium oxide $(54 \% \mathrm{Mg})$, $6.4 \%$ salt, $1.73 \%$ vitamin ADE premix, $1.09 \%$ selenium premix $(0.06 \% \mathrm{Se})$, and $0.88 \%$ trace mineral mix, and its composition (DM basis) was $11 \% \mathrm{CP}, 18 \% \mathrm{NDF}$, $5.2 \%$ fat, $14.9 \% \mathrm{Ca}, 0.35 \% \mathrm{P}, 4.58 \% \mathrm{Mg}, 0.41 \% \mathrm{~K}$, $0.31 \% \mathrm{~S}, 357 \mathrm{mg}$ of $\mathrm{Cu} / \mathrm{kg}, 1,085 \mathrm{mg}$ of $\mathrm{Zn} / \mathrm{kg}, 181 \mathrm{mg}$ of Fe $/ \mathrm{kg}, 6.67 \mathrm{mg}$ of $\mathrm{Se} / \mathrm{kg}, 125,875 \mathrm{IU} / \mathrm{kg}$ of vitamin A (retinyl acetate), 31,418 IU $/ \mathrm{kg}$ of vitamin D (activated 7-dehydrocholesterol), and $946 \mathrm{IU} / \mathrm{kg}$ of vitamin E (DL$\alpha$ tocopheryl acetate).

The study consisted of four 21-d periods with $14 \mathrm{~d}$ of adaptation followed by a 7-d collection period. The 3 consecutive days immediately following the adaptation period (d 15 to 17) were averaged and designated the baseline for DMI. Baseline feed preference and rumen conditions were determined on d 17 . On d 18, feed intakes for each diet were restricted to $75 \%$ of baseline intake. Following feed restriction, on d 19 at 0745 h, $4 \mathrm{~kg}$ (as fed) of finely ground wheat was thoroughly mixed into the rumen digesta of the cows via the rumen cannulas, initiating SARA and providing a rumen challenge. Each cow was then allowed ad libitum access 
Table 1. Chemical composition determined for corn silage, alfalfa haylage, and grass hay and DM disappearance over time determined via in situ incubation for low- and high-quality orchardgrass hay

\begin{tabular}{|c|c|c|c|c|c|c|}
\hline Item & $\begin{array}{l}\text { Corn } \\
\text { silage }\end{array}$ & $\begin{array}{c}\text { Alfalfa } \\
\text { haylage }\end{array}$ & $\begin{array}{c}\text { Low-quality } \\
\text { grass hay }\end{array}$ & $\begin{array}{l}\text { High-quality } \\
\text { grass hay }\end{array}$ & SEM & $P$-value ${ }^{1}$ \\
\hline \multicolumn{7}{|c|}{ Composition, $\%$ of DM (unless otherwise stated) } \\
\hline $\mathrm{ADF}$ & 20.2 & 33.0 & 42.7 & 33.8 & 1.07 & $<0.01$ \\
\hline $\mathrm{NDF}$ & 36.3 & 41.9 & 67.1 & 56.2 & 2.51 & 0.05 \\
\hline $\operatorname{peNDF}_{8.0}{ }^{2}$ & 50.3 & 66.4 & 22.8 & 16.6 & 2.29 & 0.15 \\
\hline NFC & 48.9 & 22.9 & 13.5 & 20.4 & 2.21 & 0.12 \\
\hline $\mathrm{NE}_{\mathrm{L}}, \mathrm{Mcal} / \mathrm{kg}$ & 0.80 & 0.65 & 0.56 & 0.66 & 0.01 & $<0.01$ \\
\hline \multicolumn{7}{|c|}{ DM disappearance, ${ }^{4} \%$} \\
\hline $0.5 \mathrm{~h}$ & - & - & 22.9 & 27.1 & 3.64 & 0.27 \\
\hline $1.0 \mathrm{~h}$ & - & - & 23.5 & 26.7 & 3.64 & 0.38 \\
\hline $2.0 \mathrm{~h}$ & - & - & 21.9 & 29.3 & 3.64 & 0.06 \\
\hline $4.0 \mathrm{~h}$ & - & - & 24.4 & 33.4 & 3.64 & 0.02 \\
\hline $48.0 \mathrm{~h}$ & - & - & 45.3 & 46.9 & 3.64 & 0.65 \\
\hline
\end{tabular}

${ }^{1} P$-value between low-quality grass hay and high-quality grass hay.

${ }^{2}$ Physically effective $\mathrm{NDF}_{8.0}=$ percentage of particles $>8.0 \mathrm{~mm} \times \mathrm{NDF}$ of whole sample.

${ }^{3}$ Physically effective $\mathrm{NDF}_{4.0}=$ percentage of particles $>4.0 \mathrm{~mm} \times \mathrm{NDF}$ of whole sample.

${ }^{4}$ Nylon bags were incubated in quadruplicate in the rumen of 2 lactating cows (each cow incubated 2 bags of each sample for each time point).

to her diet at $0800 \mathrm{~h}$. The amount of TMR offered allowed for up to approximately $115 \%$ of total daily baseline intake to be consumed. Ad libitum TMR feeding continued on d 20 and 21 to monitor recovery from the rumen challenge.

Animals were housed in individual stalls with sawdust and rubber mattresses, milked twice per day at 0500 and $1700 \mathrm{~h}$, and fed once per day at approximately $0800 \mathrm{~h}$ for a $10 \%$ refusal rate, except for the restriction day of the SARA model. Feed was pushed up 4 times/d at 1230, 1600, 2400, and $0200 \mathrm{~h}$. Rations were balanced to meet or exceed NRC (2001) requirements for cows producing $40.4 \mathrm{~kg}$ of milk/d containing $3.6 \%$ fat and $3.0 \%$ true protein, assuming a DMI of $27.2 \mathrm{~kg} / \mathrm{d}$. Water was available for ad libitum consumption.

\section{Feed, Refusal, and Particle Size Analysis}

Feed bunk contents for each animal were weighed and sampled on d 17 to 20 of each period at $0,8,16$, and $24 \mathrm{~h}$ after feeding to determine particle size distribution and DM content of the remaining feed. All samples of forage and TMR were sieved in the Penn State Particle Separator (The Pennsylvania State University, University Park), using 4 particle fractions $(\geq 19.0, \geq 8.0$, $\geq 4.0$, and $<4.0 \mathrm{~mm}$ ). Whole samples were then placed in a forced-air oven at $55^{\circ} \mathrm{C}$ for $48 \mathrm{~h}$ to determine DM content. Samples of forages were taken on d 16 and 19 and analyzed by Cumberland Valley Analytical Services Inc. (Hagerstown, MD) for CP (AOAC International, 2000), ADF (AOAC International, 2000), NDF (Van Soest et al., 1991), ash (AOAC International, 2000), NFC (Van Soest et al., 1991), and $\mathrm{NE}_{\mathrm{L}}$ (NRC, 2001). Orchardgrass hay DM disappearance was determined via in situ bags incubated in quadruplicate in the rumen of 2 lactating cows consuming a $64 \%$ forageto-36\% concentrate diet (each cow incubated 2 bags of each sample for each time point) for $0.5,1,2,4,6,8$, $12,16,24$, and $48 \mathrm{~h}$. Approximately $7 \mathrm{~g}$ of sample was sealed in a nylon bag $(10 \times 20 \mathrm{~cm}, 50-\mu \mathrm{m}$ pore size; Ankom Technology Corp., Macedon, NY) attached to a string that was secured to the rumen cannulas and weighted to anchor the bags in the center of the rumen. After removal from the rumen, bags were rinsed in cold water by hand until water was clear. Bags were then dried in a forced-air oven at $65^{\circ} \mathrm{C}$ for $48 \mathrm{~h}$ and weighed to determine remaining DM.

\section{Rumen Sampling}

Ruminal contents were collected from dorsal, ventral, cranial, caudal, and medial areas of the rumen at $0.0,1.5,3.5,5.5,8.5,11.5,14.5,18.0,21.5$, and 24.5 $\mathrm{h}$ after feeding $(0.0 \mathrm{~h}$; Kononoff et al., 2003) on d 17 to determine baseline rumen conditions, and on d 18 (feed restriction), d 19 (rumen challenge), and d 20 
(recovery). Collected digesta was mixed thoroughly and filtered through a $0.28-\mathrm{mm}$ fiberglass mesh screen (New York Wire, Mt. Wolf, PA). Rumen liquid $\mathrm{pH}$ was immediately determined using a hand-held $\mathrm{pH}$ electrode (Oakton Instruments, Vernon Hills, IL). Approximately $5 \mathrm{~mL}$ of strained ruminal fluid was placed into bottles containing $1 \mathrm{~mL}$ of $25 \%$ metaphosphoric acid and 1 $\mathrm{mL}$ of $0.6 \%$ 2-ethylbutyric acid (internal standard) and stored at approximately $-20^{\circ} \mathrm{C}$. Samples were later thawed and centrifuged 3 times at $4,000 \times g$ for 30 min at $4^{\circ} \mathrm{C}$ to obtain a clear supernatant and were analyzed for VFA concentration using gas chromatography (Yang and Varga, 1989) and $\mathrm{NH}_{3}$ using a microplate spectrophotometer (Chaney and Marbach, 1962). The concentration of lactic acid in rumen fluid was determined using a commercial lactate assay kit (Biomedical Research Service Center, Buffalo, NY) on d 19 (challenge). Samples were tested in duplicate and the lactic acid concentration was determined by reading optical density values on a microplate spectrophotometer at $492 \mathrm{~nm}$ (Iqbal et al., 2009).

\section{Milk Production and Composition}

Milk production was recorded daily and two 45-mL milk samples were taken on d 15 and 16 (4 consecutive milkings) for each cow. One sample from each milking was preserved using 2-bromo-2-nitropropane-1,3diol and was analyzed for fat, true protein, and lactose by the Dairy One milk testing laboratory (State College, PA) using infrared spectrophotometry (Foss 605B MilkoScan; Foss Electric A/S, Hillerød, Denmark). The second milk sample was centrifuged at $3,500 \times g$ for $20 \mathrm{~min}$ at $4^{\circ} \mathrm{C}$ and 300 to $350 \mathrm{mg}$ of fat cake was removed from each sample and transferred to a $2-\mathrm{mL}$, flat bottom, screw-top tube with a spatula. Fat cakes from the morning and evening milking were composited by day in proportion to fat yield at each milking. Lipid extraction of milk fat was performed according to Hara and Radin (1978) using hexane:isopropanol, and FAME were prepared by base-catalyzed transmethylation according to Chouinard et al. (1999). Fatty acid methyl esters were quantified by gas chromatography using an Agilent 6890A gas chromatograph (Agilent Technologies Inc., Palo Alto, CA) equipped with a fused-silica capillary column $(\mathrm{SP}-2560 ; 100 \mathrm{~m} \times 0.25 \mathrm{~mm}$ i.d. with $0.2-\mu \mathrm{m}$ film thickness; Supelco Inc., Bellefonte, PA), and a flame-ionization detector with hydrogen as the carrier gas. Fatty acid peaks were identified in the gas chromatographic analysis using pure methyl ester standards (GLC 60; Nu-Chek Prep Inc., Elysian, MN). An equal weight reference standard (GLC 74; Nu-Chek Prep Inc.) was used to determine correction factors for individual FA. Milk FA yield was calculated as described by Glasser et al. (2007).

\section{Statistical Analysis}

Statistical analysis was conducted using PROC MIXED of SAS (version 9.3, SAS Institute Inc., Cary, NC). Dependent variables were analyzed as a $4 \times 4$ Latin square design with fixed effects of period and treatment and random effect of cow. Sum of squares for all treatments were partitioned into single-degree-offreedom contrasts for hay quality, hay length, and hay quality by hay length interaction planned a priori. All denominator degrees of freedom for $F$-tests were calculated according to Kenward and Roger (1997), and repeated measurements for ruminal $\mathrm{pH}$, VFA, lactate, and $\mathrm{NH}_{3}$ concentrations and hay disappearance rates were analyzed using the first-order autoregressive covariance structure (Littell et al., 1998) as well as terms for time and interaction of treatment by time. Because of unequally spaced rumen sampling, the weighted mean daily ruminal $\mathrm{pH}, \mathrm{VFA}, \mathrm{NH}_{3}$, and lactate concentrations were determined by calculating the area under the response curve according to the trapezoidal rule (Shipley and Clark, 1972). Area under the curve for the SARA thresholds of $\mathrm{pH} 5.8$ and 5.5 were also calculated using the trapezoidal rule (Shipley and Clark, 1972). The incidence of SARA increases when ruminal $\mathrm{pH}$ falls below 5.8 and $\mathrm{pH}$ between 5.8 and 5.0 is often used as an indicator of SARA; therefore, a ruminal $\mathrm{pH}$ of 5.8 was used as the threshold value of SARA. All data are presented as least squares means, and treatment effects were considered significant at $P \leq 0.05$ and a trend at $0.05<P \leq 0.10$. Means separation tests were conducted using the protected least significant differences (PDIFF) procedure with significance at $P \leq 0.05$ and tendency at $P \leq 0.10$.

\section{RESULTS AND DISCUSSION}

\section{Chemical Composition of Diets}

Chemical composition of forages used in this study and the rates of DM disappearance of low- and highquality grass hay are shown in Table 1 . The chemical composition of the low- and high-quality hay was similar for $\mathrm{DM}$, ash, and $\mathrm{NFC}$; however, $\mathrm{CP}$ and $\mathrm{NE}_{\mathrm{L}}$ concentrations were higher for high-quality hay, and NDF and ADF concentrations were higher for low-quality hay. The peNDF value of particles $>8.0 \mathrm{~mm}$ were not different between the low- and high-quality chopped hay. However, a tendency $(P=0.08)$ existed for the low-quality chopped hay to have a higher peNDF $>4.0 \mathrm{~mm}$ than the 
high-quality hay. The chopped hay contained more fine particles than expected and peNDF values were low. The DM disappearance of low- and high-quality grass hay over time was different at $4,8,12,16$, and $24 \mathrm{~h}$ after incubation. High-quality grass hay had a higher rate of DM disappearance at almost all time points compared with low-quality grass hay, as would be anticipated due to the nature of the forage plants.

\section{Rumen Characteristics}

Subacute ruminal acidosis was successfully induced during this experiment. The decrease in average rumen $\mathrm{pH}$ (0.21-unit decrease) was comparable with other studies attempting to induce SARA in dairy cattle, such as Keunen et al. (2002) and Dohme et al. (2008), who reported 0.14- and 0.35-unit decreases, respectively. The area under the ruminal $\mathrm{pH}$ of 5.8 curve was increased 2 fold (236.7 to $469.0 \mathrm{pH}$ units $\times \mathrm{min} / \mathrm{d}$ ) and the area under the ruminal $\mathrm{pH}$ of 5.5 curve was increased 4.6 fold (44.4 to $203.1 \mathrm{pH}$ units $\times \mathrm{min} / \mathrm{d}$ ) on the rumen challenge day compared with baseline days. Similar areas under the curve for early-lactation cows have been reported by Dohme et al. (2008) when 3 acidosis challenges were implemented during the course of 3 consecutive experimental periods. During the first, second, and third rumen challenge, areas under the 5.8 ruminal $\mathrm{pH}$ curves were 136,231 , and $475 \mathrm{pH}$ units $\times$ $\mathrm{min} / \mathrm{d}$, respectively, and areas under the 5.5 ruminal $\mathrm{pH}$ curves were 42,91 , and $291 \mathrm{pH}$ units $\times \mathrm{min} / \mathrm{d}$, respectively. In addition, more variation existed in rumen $\mathrm{pH}$ on the rumen challenge day, as it had a lower minimum (5.05 vs. 5.34) and a higher maximum (6.80 vs. 6.62 ) over $24 \mathrm{~h}$ compared with the baseline days.

Daily average ruminal $\mathrm{pH}$ was not affected by treatment during baseline days; however, feeding $\mathrm{CH}$ and $\mathrm{TMR}+\mathrm{L}$ increased rumen $\mathrm{pH}$ on the challenge day (Table 2). It is possible that the long low-quality hay elicited a greater chewing response or buffering capacity in the rumen; however, we did not measure this. Feeding supplemental long grass hay increased minimum $\mathrm{pH}$ during the challenge day. During the recovery days, however, minimum and maximum rumen $\mathrm{pH}$ was higher for cows consuming $\mathrm{CL}$ and $\mathrm{CH}$ than $\mathrm{TMR}+\mathrm{L}$ and $\mathrm{TMR}+\mathrm{H}$. The area under the ruminal $\mathrm{pH}$ of 5.8 curve was smaller for cows consuming $\mathrm{CH}$ and $\mathrm{TMR}+\mathrm{L}$, whereas the area under the ruminal $\mathrm{pH}$ of 5.5 curve was smallest for cows consuming TMR $+\mathrm{L}$ during the challenge phase. These results indicate that supplementing the TMR with long low-quality hay may increase ruminal $\mathrm{pH}$ during SARA. The supplemental low-quality hay provided adequate peNDF to the diet.

Rumen VFA concentrations were determined to be different between days. The daily weighted average concentration for butyrate, valerate, and acetate-topropionate ratio increased, whereas the isovalerate and isobutyrate concentrations in the rumen decreased on the rumen challenge day. Feeding $4 \mathrm{~kg}$ (as-fed) highly fermentable ground wheat was thought to increase starch fermenting bacteria activity and increase concentrations of propionate; however, propionate concentrations were not affected by the rumen challenge. Acetate concentrations dramatically decreased from challenge to recovery days. Long bouts $(>3-4 \mathrm{~h}$ ) of low rumen $\mathrm{pH}$ can negatively affect fiber digestion (Russell and Wilson, 1996) and affect the activity of cellulolytic bacteria; therefore, it is possible that acetate concentration was affected after the rumen challenge and into the recovery days. These results are consistent with a similar study by Maulfair et al. (2013) in which a grainbased SARA challenge model was used. Khafipour et al. (2009) also reported similar shifts in rumen $\mathrm{pH}$ and a decrease in acetate; however, an increase in propionate and other VFA was reported, which was expected. Treatments had no effect on acetate, butyrate, or isobutyrate concentrations in the rumen during baseline and challenge days (Table 3). Low-quality grass hay increased propionate concentrations during baseline days and increasing the hay length tended to increase propionate during the challenge day. Isovalerate concentrations were higher in cows fed long grass hay than chopped grass hay. The acetate-to-propionate ratio was lower for cows consuming high-quality hay during baseline days and tended to be lower for cows consuming long supplemental hay on the challenge day. Typically, a ratio of $<2$ has been associated with SARA and decreased milk fat production (Sauvant and Mertens, 1998); however, this did not occur with any treatment during the challenge day. Concentrations of $\mathrm{NH}_{3}$ and lactate differed by length of hay during the challenge day. Cows consuming supplemental long hay had lower $\mathrm{NH}_{3}$ and lactate concentrations. Typically, lactic acid accumulates in the rumen during acute acidosis and is caused by an abrupt diet transition from high forage to high grain (Russell and Hino, 1985). During SARA, however, lactic acid does not accumulate in the rumen and lactate concentrations are minimal.

\section{Particle Size, DMI, and Refusals}

Diet refusals were analyzed for particle size distribution at $0,8,16$, and $24 \mathrm{~h}$ after feeding on the $\mathrm{d}-19$ challenge (Figure 1). Particles retained on the 19.0-mm sieve showed similar patterns over the course of the day for $\mathrm{TMR}+\mathrm{L}$ and $\mathrm{TMR}+\mathrm{H}$ treatments. The percentage of particles retained on the $19.0-\mathrm{mm}$ sieve for the CL treatment, however, increased dramatically from 0 to $16 \mathrm{~h}$ after feeding and then decreased after $16 \mathrm{~h}$. The 
Table 2. Effect of rumen challenge while offering chopped low- or high-quality hay in the TMR or long low- or high-quality hay separate from the TMR on rumen $\mathrm{pH}$

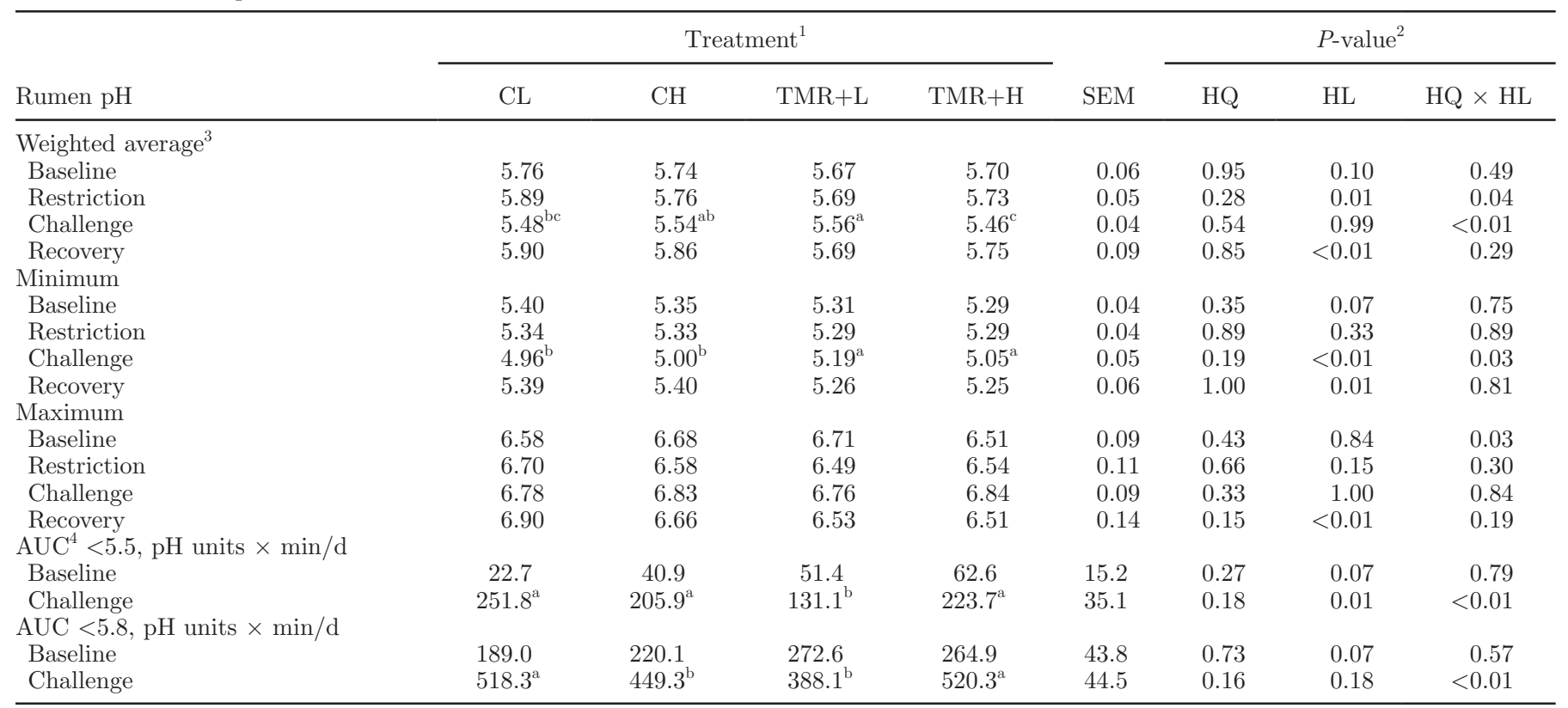

${ }^{\mathrm{a}-\mathrm{c}}$ Means within a row with different superscripts differ $(P \leq 0.05)$.

${ }^{1} \mathrm{CL}=$ chopped low-quality hay TMR; $\mathrm{CH}=$ chopped high-quality hay TMR; TMR $+\mathrm{L}=\mathrm{TMR}$ with $5.2 \%$ supplemental long low-quality hay; and $\mathrm{TMR}+\mathrm{H}=\mathrm{TMR}$ with $5.2 \%$ supplemental long high-quality hay.

${ }^{2} \mathrm{HQ}=$ main effect of hay quality; $\mathrm{HL}=$ main effect of hay length of cut; and $\mathrm{HQ} \times \mathrm{HL}=$ the interaction between the quality and length of hay. ${ }^{3}$ Weighted averages determined by calculating the area under the response curve according to the trapezoidal rule (Shipley and Clark, 1972).

${ }^{4} \mathrm{AUC}=$ area under the curve (area below $\mathrm{pH}$ threshold of 5.5 or 5.8 ).

measurement of particles retained on the 19.0-mm sieve of the Penn State Particle Separator is indicative of long particle intake (Yang and Beauchemin, 2007). Particles retained on the $8.0-\mathrm{mm}$ sieve showed similar patterns over the course of the day for each diet; these particles increased throughout the day with a larger proportion of particles retained coming from diets supplemented with long hay. Particles retained on the $4.0-\mathrm{mm}$ sieve decreased in all diets throughout the day. Particles retained on the pan decreased throughout the day in all diets, but the CL diet plateaued $16 \mathrm{~h}$ after feeding and remained at $8 \%$. These results indicate that cows were altering TMR composition through sorting, and that cows were able to sort for longer particles in the diet containing chopped low-quality hay $16 \mathrm{~h}$ after feeding and SARA induction. The SARA induction model in the current study induced SARA in a 1-d challenge and represents only 1 bout of SARA. This particular model may not be representative of chronic SARA; however, this model was effective in altering diet selection and rumen fermentation. Additionally, this model may be a closer representation to dairy farms where cows experience day-to-day variations in intake due to feeding errors or limited access to feed (Krause and Oetzel, 2005).
A significant difference existed between hay lengths for DMI on challenge and recovery days (Table 4). Cows supplemented with long hay had higher DMI than cows consuming diets with chopped hay during the SARA challenge day. Beauchemin and Yang (2005) showed that cows experiencing low ruminal $\mathrm{pH}$ will select in favor of longer forage particles, which may be an indication of the need for physically effective fiber. Cows consumed less chopped hay TMR than TMR supplemented with long hay. The chopped hay fed in the current study contained more fine particles than expected, which may have negatively affected the palatability of the TMR. Upon recovery, cows fed long high-quality hay consumed $0.32 \mathrm{~kg}$ more hay than cows fed long lowquality hay. Dry matter intake measurements for the chopped hay portion of the CL and $\mathrm{CH}$ diets was not analyzed due to the difficulty of separating and measuring out the hay from the TMR. Typically, depressed DMI becomes apparent during incidents of low rumen $\mathrm{pH}$ and, subsequently, milk production and components are compromised with suppressed DMI. Increasing dietary particle size, however, may have a positive effect on DMI when ruminal pH is low (Leonardi et al., 2005). Ultimately, during periods of low rumen $\mathrm{pH}$, it is critical to maintain DMI. 
Table 3. Effect of rumen challenge while offering chopped low- or high-quality hay in the TMR or long low- or high-quality hay separate from the TMR on rumen VFA and fermentation

\begin{tabular}{|c|c|c|c|c|c|c|c|c|}
\hline \multirow[b]{2}{*}{ Item } & \multicolumn{4}{|c|}{ Treatment $^{1}$} & \multirow[b]{2}{*}{ SEM } & \multicolumn{3}{|c|}{$P$-value ${ }^{2}$} \\
\hline & CL & $\mathrm{CH}$ & $\mathrm{TMR}+\mathrm{L}$ & $\mathrm{TMR}+\mathrm{H}$ & & HQ & HL & $\mathrm{HQ} \times \mathrm{HL}$ \\
\hline \multicolumn{9}{|c|}{ VFA weighted average, ${ }^{3} \mu \mathrm{M} / \mathrm{mL}$} \\
\hline \multicolumn{9}{|l|}{ Acetate } \\
\hline Baseline & 95.09 & 96.97 & 100.49 & 91.10 & 4.81 & 0.39 & 0.96 & 0.20 \\
\hline Challenge & 98.85 & 97.24 & 92.74 & 99.31 & 5.68 & 0.67 & 0.73 & 0.48 \\
\hline \multicolumn{9}{|l|}{ Propionate } \\
\hline \multicolumn{9}{|l|}{ Butyrate } \\
\hline Baseline & 16.95 & 16.66 & 16.94 & 16.67 & 0.82 & 0.65 & 1.00 & 0.98 \\
\hline Challenge & 19.70 & 21.14 & 21.60 & 23.08 & 2.79 & 0.58 & 0.47 & 0.99 \\
\hline \multicolumn{9}{|l|}{ Valerate } \\
\hline Baseline & 4.41 & 4.78 & 5.58 & 4.92 & 0.54 & 0.63 & 0.04 & 0.11 \\
\hline Challenge & 5.71 & 4.78 & 6.00 & 6.98 & 1.02 & 0.98 & 0.12 & 0.23 \\
\hline \multicolumn{9}{|l|}{ Isovalerate } \\
\hline \multicolumn{9}{|c|}{ Acetate:propionate } \\
\hline Baseline & 2.49 & 2.11 & 2.62 & 2.04 & 0.23 & 0.03 & 0.87 & 0.64 \\
\hline Challenge & 4.17 & 2.78 & 2.24 & 2.19 & 0.76 & 0.31 & 0.08 & 0.35 \\
\hline \multicolumn{9}{|l|}{$\mathrm{NH}_{3}, \mathrm{mg} / \mathrm{dL}$} \\
\hline \multicolumn{9}{|c|}{ Weighted mean } \\
\hline Baseline & 5.8 & 6.4 & 7.5 & 6.2 & 0.73 & 0.55 & 0.20 & 0.13 \\
\hline Challenge & 16.3 & 16.0 & 11.6 & 12.3 & 0.95 & 0.79 & $<0.01$ & 0.53 \\
\hline Recovery & 3.5 & 2.8 & 4.2 & 4.6 & 0.77 & 0.88 & 0.09 & 0.47 \\
\hline \multicolumn{9}{|c|}{ Lactate, $\mu \mathrm{m} / \mathrm{mL}$} \\
\hline Weighted m & & & & & & & & \\
\hline Challenge & 0.67 & 0.67 & 0.49 & 0.53 & 0.06 & 0.69 & 0.01 & 0.78 \\
\hline
\end{tabular}

${ }^{1} \mathrm{CL}=$ chopped low-quality hay TMR; $\mathrm{CH}=$ chopped high-quality hay TMR; TMR $+\mathrm{L}=\mathrm{TMR}$ with $5.2 \%$ supplemental long low-quality hay; and $\mathrm{TMR}+\mathrm{H}=\mathrm{TMR}$ with $5.2 \%$ supplemental long high-quality hay.

${ }^{2} \mathrm{HQ}=$ main effect of hay quality; HL = main effect of hay length of cut; and HQ $\times$ HL $=$ the interaction between the quality and length of hay. ${ }^{3}$ Weighted averages determined by calculating the area under the response curve according to the trapezoidal rule (Shipley and Clark, 1972).

\section{Milk Production and Composition}

Milk yield and composition data are reported in Table 5. Milk yield and milk component yields were not influenced by quality or length of hay. A tendency $(P$
$=0.08)$ existed for diets with low quality hay to have higher fat yield. The dietary rations were balanced for $3.6 \%$ milk fat; however, all treatments averaged below $3.4 \%$ milk fat. Low milk fat is associated with low ruminal $\mathrm{pH}$. In the current study, baseline day weighted

Table 4. Effect of rumen challenge while offering chopped low- or high-quality hay in the TMR or long low- or high-quality hay separate from the TMR on diet and hay DMI for baseline, restriction, challenge, and recovery days

\begin{tabular}{|c|c|c|c|c|c|c|c|c|}
\hline \multirow[b]{2}{*}{ Item } & \multicolumn{4}{|c|}{ Treatment $^{1}$} & \multirow[b]{2}{*}{ SEM } & \multicolumn{3}{|c|}{$P$-value ${ }^{2}$} \\
\hline & CL & $\mathrm{CH}$ & $\mathrm{TMR}+\mathrm{L}$ & $\mathrm{TMR}+\mathrm{H}$ & & HQ & HL & $\mathrm{HQ} \times \mathrm{HL}$ \\
\hline Baseline & 20.4 & 20.7 & 21.2 & 24.5 & 2.82 & 0.02 & $<0.01$ & 0.06 \\
\hline Restriction & 16.8 & 16.6 & 18.4 & 19.6 & 2.17 & 0.35 & $<0.01$ & 0.23 \\
\hline Challenge & 15.5 & 16.3 & 19.7 & 21.9 & 3.26 & 0.25 & $<0.01$ & 0.61 \\
\hline Recovery & 15.6 & 16.1 & 19.9 & 21.5 & 3.14 & 0.41 & $<0.01$ & 0.68 \\
\hline Restriction & - & - & 0.29 & 0.47 & 0.15 & 0.24 & - & - \\
\hline Challenge & - & - & 0.32 & 0.47 & 0.09 & 0.33 & - & - \\
\hline Recovery & - & - & 0.20 & 0.52 & 0.15 & 0.04 & - & - \\
\hline
\end{tabular}

${ }^{1} \mathrm{CL}=$ chopped low-quality hay TMR; $\mathrm{CH}=$ chopped high-quality hay TMR; TMR+L $=$ TMR with $5.2 \%$ supplemental long low-quality hay; and $\mathrm{TMR}+\mathrm{H}=\mathrm{TMR}$ with $5.2 \%$ supplemental long high-quality hay.

${ }^{2} \mathrm{HQ}=$ main effect of hay quality; HL = main effect of hay length of cut; and HQ $\times$ HL $=$ the interaction between the quality and length of hay. 
ruminal $\mathrm{pH}$ averages were below 5.8. As $\mathrm{pH}$ decreased below 6.0, fiber digestion was depressed, resulting in a possible limitation in milk fat synthesis. Concentrations of milk fat, protein, and lactose did not differ between treatments. In a previous study by Maulfair et al. (2010), cows sorting to a great extent were found to have no changes in milk production or rumen fermentation patterns.

Shifts in the milk FA patterns between treatments were minimal. Hay quality and length had no effect $(P$ $>0.05$ ) on milk fat proportions of $\mathrm{C}_{4}$ to $\mathrm{C}_{20}$. However, an interaction $(P=0.02)$ was seen between hay quality and length for cis-9,trans-11 CLA. More cis-9,trans-11 CLA was found in the milk of cows consuming TMR $+\mathrm{L}$ $(0.81 \mathrm{~g} / 100 \mathrm{~g}$ of total FA) compared with $\mathrm{TMR}+\mathrm{H}$ $(0.50 \mathrm{~g} / 100 \mathrm{~g}$ of total FA) and CL $(0.54 \mathrm{~g} / 100 \mathrm{~g}$ of total FA). Short-chain FA $\left(\mathrm{C}_{10}\right.$ to $\left.\mathrm{C}_{14: 1}\right)$ are mainly derived from de novo synthesis in the mammary gland of dairy cows (Kennelly and Glimm, 1998); thus, the absence of dietary treatment effects on milk fat levels of these short-chain FA suggests that a similar extent of mammary de novo synthesis was occurring.

\section{CONCLUSIONS}

Under the conditions of this study, we determined that feeding cows long low-quality hay separate from the TMR during the SARA challenge and chopped high- or low-quality hay during the recovery phase increased rumen $\mathrm{pH}$. Overall, cows fed supplemental long hay had greater DMI during baseline and challenge days compared with cows consuming chopped hay. Cows had a greater preference for high-quality long hay during recovery days. Minimal differences among diets were found for TMR particle size selection during the challenge day; however, $16 \mathrm{~h}$ after feeding, cows
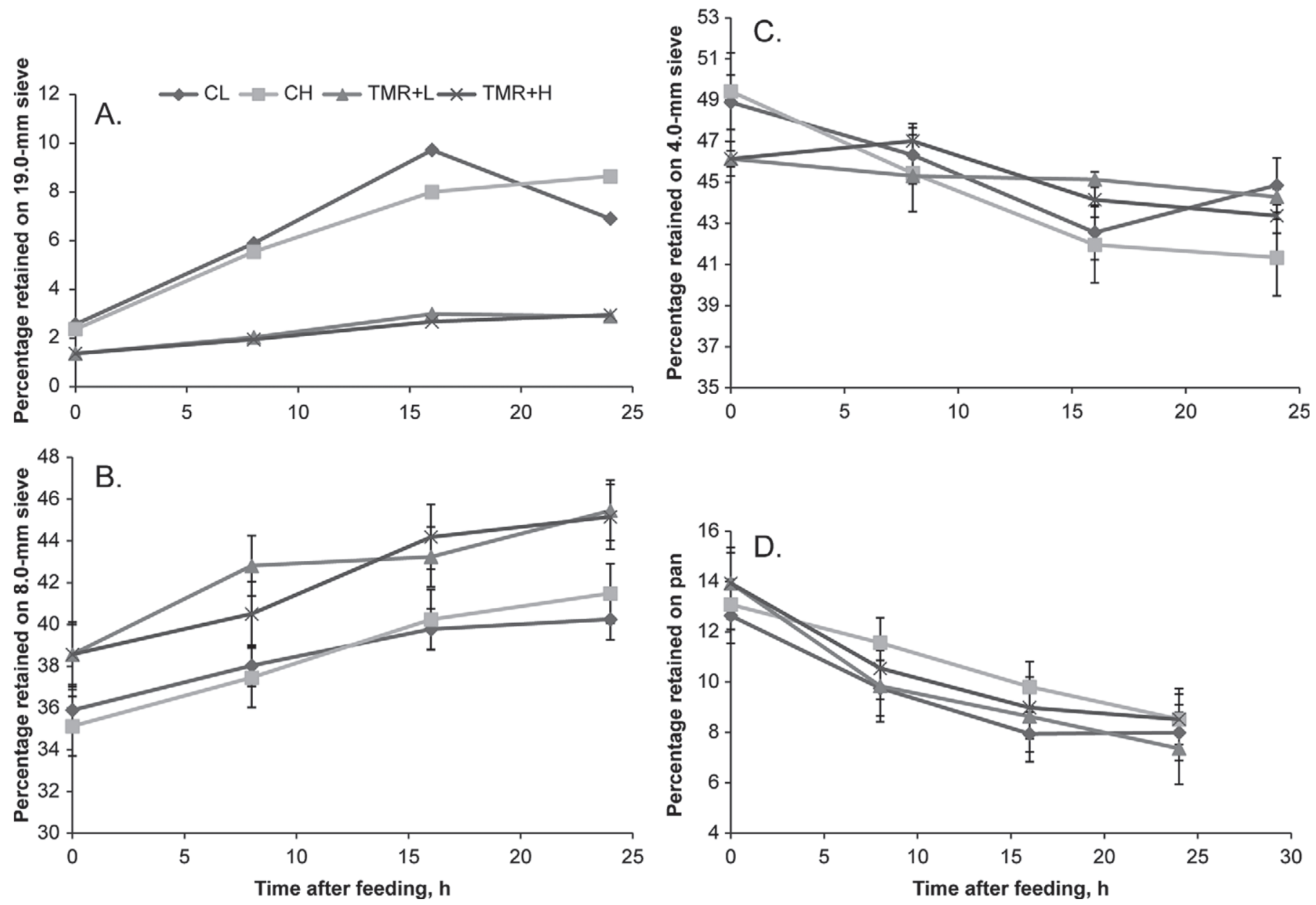

Figure 1. Effect of rumen challenge (d 19) while offering chopped low- or high-quality hay in the TMR or long low- or high-quality hay separate from the TMR on refusal particle size distribution for 19.0- (A), 8.0- (B), and 4.0-mm (C) sieves, and the pan (D). CL = 5.2\% chopped low-quality hay TMR; $\mathrm{CH}=5.2 \%$ chopped high-quality hay $\mathrm{TMR} ; \mathrm{TMR}+\mathrm{L}=\mathrm{TMR}$ with $5.2 \%$ supplemental long low-quality hay; TMR $+\mathrm{H}=$ TMR with $5.2 \%$ supplemental long high-quality hay. 
Table 5. Effect of feeding chopped low- or high-quality hay in the TMR or long low- or high-quality hay separate from the TMR on milk production and components

\begin{tabular}{|c|c|c|c|c|c|c|c|c|}
\hline \multirow[b]{2}{*}{ Item } & \multicolumn{4}{|c|}{ Treatment $^{1}$} & \multirow[b]{2}{*}{ SEM } & \multicolumn{3}{|c|}{$P$-value ${ }^{2}$} \\
\hline & CL & $\mathrm{CH}$ & $\mathrm{TMR}+\mathrm{L}$ & $\mathrm{TMR}+\mathrm{H}$ & & HQ & $\mathrm{HL}$ & $\mathrm{HQ} \times \mathrm{HL}$ \\
\hline Fat, $\%$ & 3.32 & 3.17 & 3.19 & 3.23 & 0.26 & 0.49 & 0.69 & 0.22 \\
\hline Fat, $\mathrm{kg} / \mathrm{d}$ & 1.24 & 1.19 & 1.24 & 1.17 & 0.18 & 0.08 & 0.85 & 0.81 \\
\hline Protein, \% & 3.01 & 3.12 & 3.03 & 3.02 & 0.08 & 0.43 & 0.53 & 0.31 \\
\hline Lactose, $\mathrm{kg} / \mathrm{d}$ & 1.88 & 1.88 & 1.95 & 1.82 & 0.27 & 0.21 & 0.98 & 0.28 \\
\hline
\end{tabular}

${ }^{1} \mathrm{CL}=$ chopped low-quality hay TMR; $\mathrm{CH}=$ chopped high-quality hay TMR; TMR+L = TMR with $5.2 \%$ supplemental long low-quality hay; and $\mathrm{TMR}+\mathrm{H}=\mathrm{TMR}$ with $5.2 \%$ supplemental long high-quality hay.

${ }^{2} \mathrm{HQ}=$ main effect of hay quality; $\mathrm{HL}=$ main effect of hay length of cut; and $\mathrm{HQ} \times \mathrm{HL}=$ the interaction between the quality and length of hay. ${ }^{3} 3.5 \% \mathrm{FCM}=0.432(\mathrm{~kg}$ of milk) +16.23 ( $\mathrm{kg}$ of fat) (Gaines, 1928).

selected for longer particles retained on the 19.0-mm sieve. Cows started to sort for chopped low-quality hay from 16 to $24 \mathrm{~h}$ after SARA induction. Milk production and components did not differ among treatments. Milk FA profile was marginally altered by treatment. Results of this study indicate that feeding supplemental long hay may be a suitable strategy to help maintain DMI during incidents of and recovery from periods of low ruminal $\mathrm{pH}$.

\section{REFERENCES}

AOAC International. 2000. Official Methods of Analysis. 17th ed. AOAC International, Arlington, VA.

Beauchemin, K. A., and W. Z. Yang. 2005. Effects of physically effective fiber on intake, chewing activity, and ruminal acidosis for dairy cows fed diets based on corn silage. J. Dairy Sci. 88:2117-2129.

Chaney, A. L., and E. P. Marbach. 1962. Modified reagents for determination of urea and ammonia. Clin. Chem. 8:130-132.

Chouinard, P. Y., L. Corneau, D. M. Barbano, L. E. Metzger, and D. E. Bauman. 1999. Conjugated linoleic acids alter milk fatty acid composition and inhibit milk fat secretion in dairy cows. J. Nutr. 129:1579-1584.

DeVries, T. J., F. Dohme, and K. A. Beauchemin. 2008. Repeated ruminal acidosis challenges in lactating dairy cows at high and low risk for developing acidosis: Feed sorting. J. Dairy Sci. 91:39583967.

Dohme, F., T. J. DeVries, and K. A. Beauchemin. 2008. Repeated ruminal acidosis challenges in lactating dairy cows at high and low risk for developing acidosis: Ruminal pH. J. Dairy Sci. 91:35543567.

Gaines, W. L. 1928. The energy basis of measuring milk yield in dairy cows. Illinois Agric. Exp. Sta. Bull. 308. University of Illinois Agricultural Experiment Station, Urbana.

Glasser, F., M. Doreau, A. Ferlay, and Y. Chilliard. 2007. Technical note: Estimation of milk fatty acid yield from milk fat data. J. Dairy Sci. 90:2302-2304.

Gozho, G. N., J. C. Plaizier, D. O. Krause, A. D. Kennedy, and W. M. Wittenberg. 2005. Subacute ruminal acidosis induces ruminal lipopolysaccharide release and triggers an inflammatory response. J. Dairy Sci. 88:1399-1403.

Hara, A., and N. S. Radin. 1978. Lipid extraction of tissues with a low-toxicity solvent. Anal. Biochem. 90:420-426.

Iqbal, S., Q. Zebeli, A. Mazzolari, G. Bertoni, S. M. Dunn, W. Z. Yang, and B. N. Ametaj. 2009. Feeding barley grain steeped in lactic acid modulates rumen fermentation patterns and increases milk fat content in dairy cows. J. Dairy Sci. 92:6023-6032.

Kennelly, J. J., and D. R. Glimm. 1998. The biological potential to alter the composition of milk. Can. J. Anim. Sci. 78(Suppl.):23-56.

Kenward, M. G., and J. H. Roger. 1997. Small sample inference for fixed effects from restricted maximum likelihood. Biometrics 53:983-997.

Keunen, J. E., J. C. Plaizier, L. Kyriazakis, T. F. Duffield, T. M. Widowski, M. I. Lindinger, and B. W. McBride. 2002. Effects of a subacute ruminal acidosis model on the diet selection of dairy cows. J. Dairy Sci. 85:3304-3313.

Khafipour, E., D. O. Krause, and J. C. Plaizier. 2009. A grain-based subacute ruminal acidosis challenge causes translocation of lipopolysaccharide and triggers inflammation. J. Dairy Sci. 92:1060 1070.

Kleen, J. L., G. A. Hooijer, J. Rehage, and J. P. T. M. Noordhuizen. 2003. Subacute ruminal acidosis (SARA): A review. J. Vet. Med. Ser. A Physiol. Pathol. Clin. Med. 50:406-414.

Kononoff, P. J., A. J. Heinrichs, and H. A. Lehman. 2003. The effect of corn silage particle size on eating behavior, chewing activities, and rumen fermentation in lactating dairy cows. J. Dairy Sci. 86:3343-3353.

Krause, K. M., and G. R. Oetzel. 2005. Inducing subacute ruminal acidosis in lactating dairy cows. J. Dairy Sci. 88:3633-3639.

Krause, K. M., and G. R. Oetzel. 2006. Understanding and preventing subacute ruminal acidosis in dairy herds: A review. Anim. Feed Sci. Technol. 126:215-236.

Leonardi, C., K. J. Shinners, and L. E. Armentano. 2005. Effect of different dietary geometric mean particle length and particle size distribution of oat silage on feeding behavior and productive performance of dairy cattle. J. Dairy Sci. 88:698-710.

Littell, R. C., P. R. Henry, and C. B. Ammerman. 1998. Statistical analysis of repeated measures data using SAS procedures. J. Anim. Sci. 76:1216-1231.

Maulfair, D. D., K. K. McIntyre, and A. J. Heinrichs. 2013. Subacute ruminal acidosis and total mixed ration preference in lactating dairy cows. J. Dairy Sci. 96:6610-6620.

Maulfair, D. D., G. I. Zanton, M. Fustini, and A. J. Heinrichs. 2010. Effect of feed sorting on chewing behavior, production, and rumen fermentation in lactating dairy cows. J. Dairy Sci. 93:4791-4803.

Mertens, D. R. 1997. Creating a system for meeting the fiber requirements of dairy cows. J. Dairy Sci. 80:1463-1481.

NRC. 2001. Nutrient Requirements of Dairy Cattle. 7th rev. ed. Natl. Acad. Press, Washington, DC.

Nocek, J. E. 1997. Bovine acidosis: Implications on laminitis. J. Dairy Sci. 80:1005-1028.

Russell, J. B., and T. Hino. 1985. Regulation of lactate production in Streptococcus bovis: A spiraling effect that contributes to rumen acidosis. J. Dairy Sci. 68:1712-1721. 
Russell, J. B., and D. B. Wilson. 1996. Why are ruminal cellulolytic bacteria unable to digest cellulose at low $\mathrm{pH}$ ? J. Dairy Sci. 79:1503-1509.

Sauvant, D., and D. R. Mertens. 1998. Dietary characteristics affecting ruminal acidosis. Pages 63-65 in Annual Research Summaries 1988. US Dairy Forage Research Center, Madison, WI.

Shipley, R. A., and R. E. Clark. 1972. Tracer Methods for In Vivo Kinetics. Academic Press, New York, NY.

Van Soest, P. J., J. B. Robertson, and B. A. Lewis. 1991. Methods for dietary fiber, neutral detergent fiber, and nonstarch polysaccharides in relation to animal nutrition. J. Dairy Sci. 74:3583-3597.

Yang, C.-M. J., and G. A. Varga. 1989. Effect of three concentrate feeding frequencies on rumen protozoa, rumen digesta kinetics, and milk yield in dairy cows. J. Dairy Sci. 72:950-957.
Yang, W. Z., and K. A. Beauchemin. 2006. Physically effective fiber: Method of determination and effects on chewing, ruminal acidosis, and digestion by dairy cows. J. Dairy Sci. 89:2618-2633.

Yang, W. Z., and K. A. Beauchemin. 2007. Altering physically effective fiber intake through forage proportion and particle length: Chewing and ruminal pH. J. Dairy Sci. 90:2826-2838.

Yang, W. Z., K. A. Beauchemin, and L. M. Rode. 2001. Effects of grain processing, forage to concentrate ratio, and forage particle size on rumen $\mathrm{pH}$ and digestion by dairy cows. J. Dairy Sci. 84:2203-2216. 